\title{
Assessment of the Radiation Hazard Indices from Terrestrial Radiation in Mining Sites in Benue State, Nigeria
}

\author{
A. I. Olanrewaju ${ }^{1 *}$ and G. O. Avwiri ${ }^{1}$ \\ ${ }^{1}$ Department of Physics, Environmental and Radiation Physics Research Group, \\ University of Port Harcourt, Rivers State, Nigeria.
}

\begin{abstract}
Authors' contributions
This work was carried out in collaboration between both authors. Authors AIO and GOA designed the study. Author AlO performed the statistical analysis, wrote the protocol and wrote the first draft of the manuscript. Author GOA supervised and managed the analyses of the study. Both authors read and approved the final manuscript.

Article Information

DOI: $10.9734 / A J E E / 2017 / 33373$

Editor(s):

(1) Wen-Cheng Liu, Department of Civil and Disaster Prevention Engineering, National United University, Taiwan and Deputy Director General, Taiwan Typhoon and Flood Research Institute, National United University, Taipei, Taiwan.

Reviewers:

(1) Paul Oakley, Canada (2) Krishan Kant, Aggarwal PG College, Ballabgarh, India.

(3) Rajinder Tiwari, Amity University, Lucknow, India. Complete Peer review History: http://www.sciencedomain.org/review-history/19214
\end{abstract}

Original Research Article

Received 12 $2^{\text {th }}$ April 2017

Accepted $12^{\text {th }}$ May 2017

Published 27 ${ }^{\text {th }}$ May 2017

\section{ABSTRACT}

The assessment of the radiation hazard indices of solid minerals and sand in mining sites of Benue State, Nigeria was carried out using well calibrated radalert-50 and 100 meters and a Global Positioning System (Garmin 765). The sites investigated are Lessle (Barite), Gboko (Limestone), Owukpa (Coal) and Akuana (Salt) deposits fields. The mean background radiation ionization exposure rate of $0.019 \pm 0.004,0.019 \pm 0.004,0.014 \pm 0.002$ and $0.023 \pm 0.005 \mathrm{mRh}^{-1}$ were obtained respectively. The mean of absorbed dose rates estimated for the mining fields are 161.53, 169.40, 120.35 and $201.84 \mathrm{nGy} / \mathrm{hr}$ respectively. Estimated values of the annual effective dose equivalent (AEDE) for outdoor exposures $0.25,0.26,1.61$, and $2.71 \mathrm{mSv} / \mathrm{yr}$ respectively while the mean excess lifetime cancer risk calculated for the mine fields values are $(0.82,0.86,5.33$ and 8.94$) \mathrm{x}$ $10^{-3}$ respectively. The obtained values for background ionizing radiation were higher than the recommended standard limits by ICRP while the AEDE calculated in the entire mine fields are 
within safe values but the absorbed dose (D) and excess lifetime cancer risk (ELCR) estimated were higher than their world permissible values of $89 \mathrm{nGy} / \mathrm{hr}$ and $0.29 \times 10^{-3}$ respectively. The work indicated that there is tendency for the residents near the mining sites to get high radiation doses and could develop radiation-related illness after a long time exposure.

Keywords: Solid minerals; radalert-(50 and 100); radioactivity; excess lifetime cancer risk and effective dose.

\section{INTRODUCTION}

Mining industries have been viewed as key drivers of economic growth and the development process [1]. Due to the presence of mineral deposits of economically viable grades, mining and extraction of metals are carried out in such mineralised zones of Benue State, Nigeria. Mining activities all over the world have contributed immensely to the disequilibrium of mineral elements and therefore affect the terrestrial ecosystem due to the excavation of large amount of sands [2].

Natural radioactivity is widespread in the earth environment and it exists in various geological formations such as earth crust, rocks, soils, plants, water and air. When rocks are disintegrated through natural process, radionuclides are carried to soil by rain and flows [3]. The ways minerals incorporate the radionuclide depend on several geological conditions, but is most strongly dependent on the mineral species and geological formation from which they originate.

Exposure to all these radiations from the mineral mining sites that has been contaminated with radioactive waste may pose a threat to human health. Furthermore, consuming water and fishery resources may cause internal exposure which can lead to radiation related sicknesses like cancer, turmour and sterility [4]. Several studies of radiological survey have been carried out in some mineral mining sites in Nigeria and outside the country to monitor radiation level and it's associated radiation risk [5-10]. None of the investigations done in similar environment in Nigeria determined level of radiological burden for different range of minerals of exposure to such background radiations. Hence, there is need to investigate the present radioactivity status of the mineral mining sites.

This work assessed the background radiation level of mining sites in Benue State and its surroundings and to estimate the radiation risk parameters in order to assess its biological effect to exposed populace.

\section{MATERIALS AND METHODS}

\subsection{Study Area}

The study areas are located in Benue State which lies within the lower river Benue trough in the middle belt region of Nigeria and are within the geographical points situated on longitude $7^{\circ}$ $47^{\prime}$ and $10^{\circ} 0^{\prime}$ East and Latitude $6^{\circ} 25^{\prime}$ and $8^{\circ} 8^{\prime}$ North. The geology of the study area is principally of sedimentary formation with pockets of basement complex which is made up of sandstones, mudstones and limestone that influences both surface and ground water availability $[11,12]$. Benue State is endowed with solid mineral resources such as industrial minerals - barites, kaolin, gypsum, limestone; Energy mineral - coal, Chemical mineral - brine; Metallic mineral - wolframite, bentonite clay, lead and zinc etc, which are evenly distributed over the existing geographical location, some of which are not yet being mined but are being investigated [13]. Fig. 1 shows the location map of the study area.

\subsection{Field Measurements}

The in situ measurements of the terrestrial radiation from the surface of the soil of the mine fields were done directly in an undisturbed manner. Using a well calibrated rad-monitor, Digilert - 50 and Radalert - 100 nuclear radiation monitoring meter (S.E. International Incorporation, Summer Town, USA), containing a Geiger-Muller tube capable of detecting alpha, beta, gamma and $\mathrm{X}$-rays within the temperature range of $10^{\circ} \mathrm{C}$ and $50^{\circ} \mathrm{C}$. The Giegermuller tube generates a pulse current each time radiation passes through the tube and causes ionization [14]. Each pulse is electronically detected and registered as a count. The radiation meters were calibrated with a ${ }^{137} \mathrm{Cs}$ source of a specific 


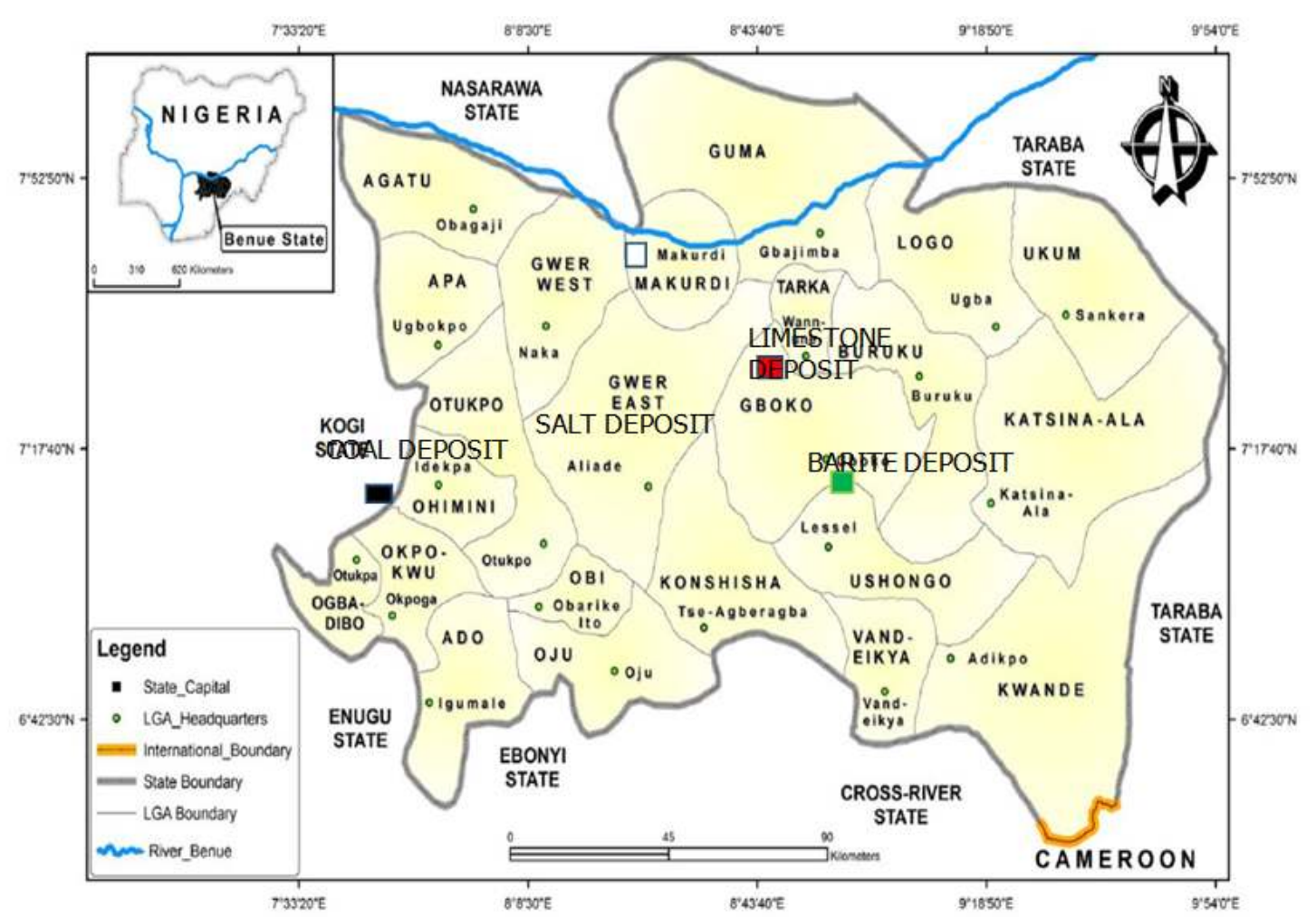

Fig. 1. Map of the study area

energy and set to measure exposure rate in milliRoentgen per hour $\left(\mathrm{mRhr}^{-1}\right)$. The meter has an accuracy of $\pm 15 \%$. The measurements were carried out by positioning the radiation meter at the targeted sample (rock aggregates and surface samples) located at varying distance from the mineral deposit mine field(s) established by Geographical Positioning System (GPS). Measurements were taken within the hours necessary since exposure rate meter has a peak response to environmental radiation within these hours, then the background radiation level was recorded. In order to ensure quality assurance the provisions taken include: Two measuring instruments was deplored to field and standardization of the measuring instruments before use was done, multiplicity of measurement for each sample point $(n=4$ for radiation measurements for each sample point). The switch (knob) was turned to return the meter to zero after each measurement.

\subsection{Data Analysis/Conversion}

The generated data were converted to absorbed dose rate $n G y h^{-1}$ using the relation for the external exposure rate by [9].

$$
\begin{aligned}
& 1 \mu R / h=8.7 n G y / h= \\
& 8.7 \times 10^{-3} \mu G y /(1 / 8760 y),
\end{aligned}
$$

The results are presented as means and standard deviations while the bar chart illustrations were carried out to determine the significant relationships between the radiations from different sample types as shown in Tables 1-4.

\section{RESULTS AND DISCUSSION}

\subsection{Results}

The results for the in-situ measurement of terrestrial radiation level and the calculated values for gamma dose, annual effective dose equivalent (AEDE) and excess lifetime cancer risk (ELCR) of the barite, limestone, coal and salt mining fields are presented in Tables 1-4 and while Table 5 presents the summary of parameters calculated. Figs. 2 and 3 show the comparison of excess lifetime cancer risk with average world standard value for barite, limestone, coal and salt mining fields respectively. 


\subsection{Radiation Risk Parameters}

The data obtained for the radiation exposure rate and the absorbed dose does not actually provide the exact indication about the total radiation hazards. The $\gamma$ radiation hazards as a result of the exposure to background ionizing radiation in selected mining fields and its environs are estimated by calculating radiation risk parameters.

Table 1. The mean radiation exposure rate and estimated radiation risk parameters of the barite mineral deposits fields in Lessle area

\begin{tabular}{|c|c|c|c|c|c|}
\hline $\begin{array}{l}\text { Sample } \\
\text { location }\end{array}$ & $\begin{array}{l}\text { Geographical } \\
\text { positions }\end{array}$ & $\begin{array}{l}\text { AVE. RAD. } \\
\text { value } \mathrm{mRhr}^{-1}\end{array}$ & $\begin{array}{l}\text { Absorbed dose } \\
\text { nGy/hr }\end{array}$ & $\begin{array}{l}\text { AEDE } \\
\text { (mSv/yr) }\end{array}$ & $\begin{array}{l}\text { ELCR } \\
\times 10^{-3} \\
\end{array}$ \\
\hline Lessle area & $\begin{array}{l}\text { N0708'11.2"' } \\
\text { E00901'28.1" }\end{array}$ & $0.021 \pm 0.004$ & 182.7 & 0.2401 & 0.7922 \\
\hline $\begin{array}{l}\text { Ge-Mbagwa } \\
\text { area }\end{array}$ & $\begin{array}{l}\text { N0707'46.4" } \\
\text { E00900'49.7" }\end{array}$ & $0.019 \pm 0.005$ & 165.3 & 0.2667 & 0.8802 \\
\hline $\begin{array}{l}\text { Akegh-Dyege } \\
\text { area }\end{array}$ & $\begin{array}{l}\text { N0708'01.7" } \\
\text { E00901'00.1" }\end{array}$ & $0.032 \pm 0.005$ & 278.4 & 0.4268 & 1.4084 \\
\hline Ushongo & $\begin{array}{l}\text { N0708'07.4" } \\
\text { E00901'20.8" }\end{array}$ & $0.019 \pm 0.008$ & 165.3 & 0.2267 & 0.7482 \\
\hline Mbakoa & $\begin{array}{l}\text { N0708'34.4" } \\
\text { E00901'24.5" }\end{array}$ & $0.018 \pm 0.004$ & 156.6 & 0.2667 & 0.8802 \\
\hline Nyamge area & $\begin{array}{l}\text { N0708'19.5" } \\
\text { E00901'30.2" }\end{array}$ & $0.017 \pm 0.003$ & 147.9 & 0.1867 & 0.6162 \\
\hline $\begin{array}{l}\text { Ushongo } \\
\text { community(Host) }\end{array}$ & $\begin{array}{l}\text { N0708'11.0" } \\
\text { E00901'16.4" }\end{array}$ & $0.011 \pm 0.008$ & 95.7 & 0.1467 & 0.4841 \\
\hline Mean field value & & $0.019 \pm 0.004$ & 161.5 & 0.2476 & 0.8172 \\
\hline
\end{tabular}

Table 2. The mean radiation exposure rate and estimated radiation risk parameters of the limestone mineral deposits fields in Gboko area

\begin{tabular}{|c|c|c|c|c|c|}
\hline $\mathbf{S} / \mathbf{N}$ & $\begin{array}{l}\text { Geographical } \\
\text { positions }\end{array}$ & $\begin{array}{l}\text { AVE. RAD. } \\
\text { value } \mathrm{mRhr}^{-1}\end{array}$ & $\begin{array}{l}\text { Absorbed } \\
\text { dose } \\
\text { nGy/hr }\end{array}$ & $\begin{array}{l}\text { AEDE } \\
(\mathrm{mSv} / \mathrm{yr})\end{array}$ & $\begin{array}{l}\text { ELCR } \\
\times 10^{-3}\end{array}$ \\
\hline Amua & $\begin{array}{l}\text { N0724'38.2"' } \\
\text { E00859'01.0" }\end{array}$ & $0.021 \pm 0.005$ & 182.7 & 0.2267 & 0.7482 \\
\hline $\begin{array}{l}\text { Limestone deposit } \\
\text { Ridge }\end{array}$ & $\begin{array}{l}\text { N07'24'45.7"' } \\
\text { E00858'43.1" }\end{array}$ & $0.019 \pm 0.005$ & 165.3 & 0.1734 & 0.5722 \\
\hline Gboko-Yandev & $\begin{array}{l}\text { N0724'52.2" } \\
\text { E00858'27.9" }\end{array}$ & $0.018 \pm 0.003$ & 156.6 & 0.1600 & 0.5281 \\
\hline Gboko community 1 & $\begin{array}{l}\text { N0724'36.0" } \\
\text { E00858'55.2" }\end{array}$ & $0.017 \pm 0.008$ & 147.9 & 0.3068 & 1.0123 \\
\hline $\begin{array}{l}\text { Limestone deposit } \\
\text { Pit }\end{array}$ & $\begin{array}{l}\text { N0724'17.1" } \\
\text { E00858'42.8" }\end{array}$ & $0.020 \pm 0.005$ & 174.0 & 0.2667 & 0.8802 \\
\hline Gboko factory & $\begin{array}{l}\text { N0724'00.8" } \\
\text { E00858'31.9" }\end{array}$ & $0.031 \pm 0.001$ & 269.7 & 3.6218 & 11.952 \\
\hline $\begin{array}{l}\text { AMUA } \\
\text { community(Host) }\end{array}$ & $\begin{array}{l}\text { N07'24'38.2', } \\
\text { E00859'01.0', }\end{array}$ & $0.013 \pm 0.007$ & 113.1 & 0.1734 & 0.5722 \\
\hline Mean field value & & 0.019 & 169.36 & 0.25963 & 0.8567 \\
\hline
\end{tabular}


Table 3. The mean radiation exposure rate and estimated radiation risk parameters of the coal mineral deposits fields in Owukpa-Orokam area

\begin{tabular}{|c|c|c|c|c|c|}
\hline Sample area & $\begin{array}{l}\text { Geographical } \\
\text { positions }\end{array}$ & $\begin{array}{l}\text { AVE. RAD. } \\
\text { value } \mathrm{mRhr}^{-1}\end{array}$ & $\begin{array}{l}\text { Absorbed } \\
\text { dose } n G y / h r\end{array}$ & $\begin{array}{l}\text { AEDE } \\
(\mathrm{mSv} / \mathrm{yr})\end{array}$ & ELCR $\times 10^{-3}$ \\
\hline Otukpo area & $\begin{array}{l}\text { N0658'44.1" } \\
\text { E00737'05.3" }\end{array}$ & $0.011 \pm 0.002$ & 95.7 & 1.5188 & 5.0121 \\
\hline Orokam area & $\begin{array}{l}\text { N0658'40.9"' } \\
\text { E007936'45.7" }\end{array}$ & $0.014 \pm 0.002$ & 121.8 & 1.7525 & 5.7832 \\
\hline Otupka area & $\begin{array}{l}\text { N0657'12.4" } \\
\text { E00737'00.4" }\end{array}$ & $0.024 \pm 0.004$ & 208.8 & 2.8040 & 9.2532 \\
\hline Owupka area & $\begin{array}{l}\text { N0657'18.2" } \\
\text { E00737'12.5" }\end{array}$ & $0.021 \pm 0.002$ & 182.7 & 2.4535 & 8.0965 \\
\hline Bagba area & $\begin{array}{l}\text { N0657'24.4" } \\
\text { E00737'54.0" }\end{array}$ & $0.016 \pm 0.005$ & 139.2 & 2.4535 & 8.0965 \\
\hline $\begin{array}{l}\text { Bagba } \\
\text { community }\end{array}$ & $\begin{array}{l}\text { N0657'32.5" } \\
\text { E007937'03.4" }\end{array}$ & $0.013 \pm 0.002$ & 113.1 & 1.6357 & 5.3977 \\
\hline $\begin{array}{l}\text { Owupka } \\
\text { community (Host) }\end{array}$ & $\begin{array}{l}\text { N0656'58.1" } \\
\text { E00737'22.3" }\end{array}$ & $0.008 \pm 0.003$ & 69.6 & 0.9347 & 3.0844 \\
\hline Mean field value & & 0.014 & 120.35 & 1.61 & 5.33 \\
\hline
\end{tabular}

Table 4. The mean radiation exposure rate and estimated radiation risk parameters of the salt mineral deposits fields in Akuana area

\begin{tabular}{|c|c|c|c|c|c|}
\hline Sampled area & $\begin{array}{l}\text { Geographical } \\
\text { positions }\end{array}$ & $\begin{array}{l}\text { AVE. RAD. } \\
\text { value } \mathrm{mRhr}^{-1}\end{array}$ & $\begin{array}{l}\text { Absorbed } \\
\text { dose } \\
\text { nGy/hr }\end{array}$ & $\begin{array}{l}\text { AEDE } \\
(\mathrm{mSv} / \mathrm{yr})\end{array}$ & $\begin{array}{l}\text { ELCR } \\
\times 10^{-3}\end{array}$ \\
\hline Akuana phase 1 & $\begin{array}{l}\text { N07'47'02.6"' } \\
\text { E00909'48.3" }\end{array}$ & $0.025 \pm 0.006$ & 217.5 & 2.57 & 8.48 \\
\hline Akuana salt lake & $\begin{array}{l}\text { N0747'04.8'" } \\
\text { E00909'35.6" }\end{array}$ & $0.034 \pm 0.004$ & 295.8 & 3.97 & 13.11 \\
\hline Akuana phase 2 & $\begin{array}{l}\text { N07\%47'01.5"' } \\
\text { E00909'42.5" }\end{array}$ & $0.022 \pm 0.002$ & 191.4 & 3.15 & 10.40 \\
\hline Akuana phase 3 & $\begin{array}{l}\text { N07\%47'58.0"' } \\
\text { E00909'49.9" }\end{array}$ & $0.021 \pm 0.005$ & 182.7 & 3.04 & 10.02 \\
\hline Akuana phase 4 & $\begin{array}{l}\text { N07\%47'05.6"' } \\
\text { E00909'53.3" }\end{array}$ & $0.031 \pm 0.005$ & 269.7 & 3.62 & 11.95 \\
\hline $\begin{array}{l}\text { Akuana community } \\
\text { (Host) }\end{array}$ & $\begin{array}{l}\text { N07'47'08.1'” } \\
\text { E00909'53.4"' }\end{array}$ & $0.016 \pm 0.007$ & 139.2 & 1.87 & 6.17 \\
\hline Mean field value & & 0.023 & 201.8 & 2.71 & 8.94 \\
\hline
\end{tabular}

Table 5. Summary of the measured exposure rate and the estimated radiation hazard parameters

\begin{tabular}{|c|c|c|c|c|}
\hline amples/ areas & $\begin{array}{l}\text { Background ionizing } \\
\text { radiations (Mean) } \\
\left(\mathrm{mRhr}^{-1}\right)\end{array}$ & $\begin{array}{l}\text { Absorbed dose } \\
\text { rates (Mean) } \\
\left(\text { nGyhr }^{-1}\right)\end{array}$ & $\begin{array}{l}\text { Annual effective } \\
\text { dose equivalent } \\
\text { (Mean) (mSvyr }{ }^{-1} \text { ) }\end{array}$ & $\begin{array}{l}\text { Excess lifetime } \\
\text { cancer risk }\left(10^{-3}\right) \\
\text { (Mean) }\end{array}$ \\
\hline & & $147.9-278.4(161$ & & \\
\hline mest & 0. & & & \\
\hline & & & & \\
\hline alt (Akuan & $0.021-0.034(\mathbf{0 . 0 2 3 )}$ & $182.7-295.8(\mathbf{2 0 1 . 8 4})$ & $2.57-3.97(2.71)$ & $8.48-13.11(8.94)$ \\
\hline
\end{tabular}




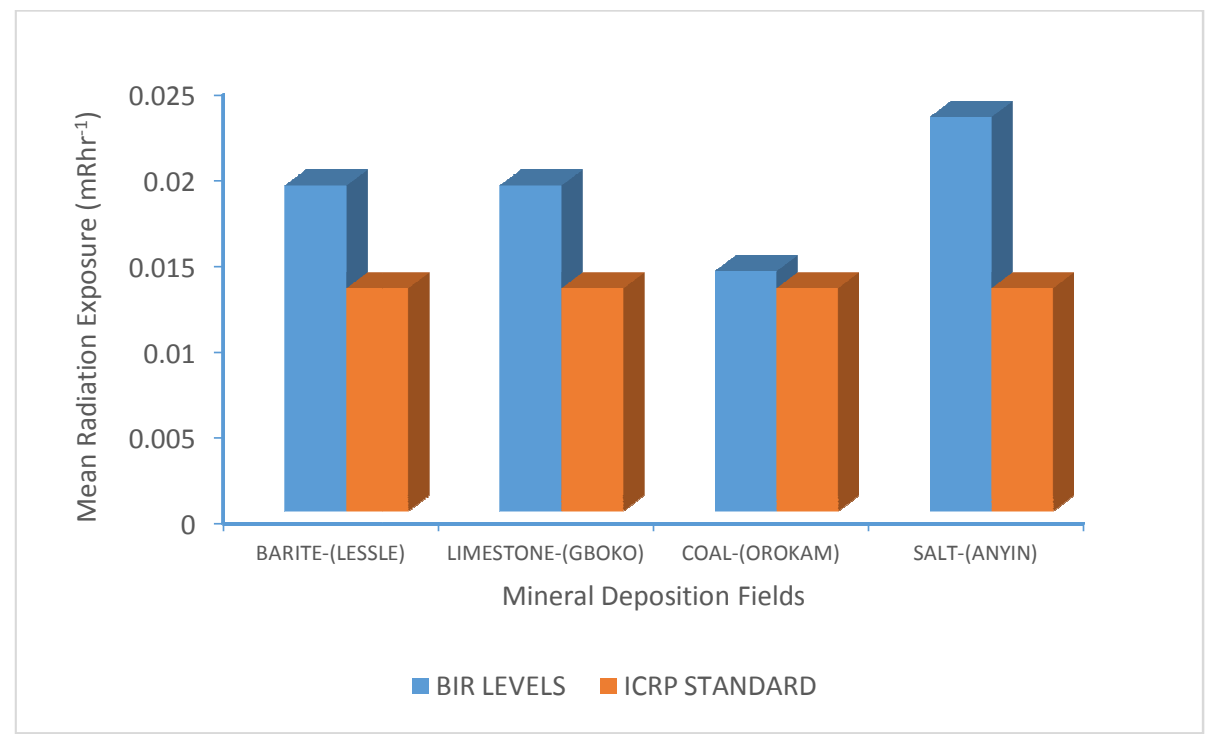

Fig. 2. Comparison of measured BIR levels with standard

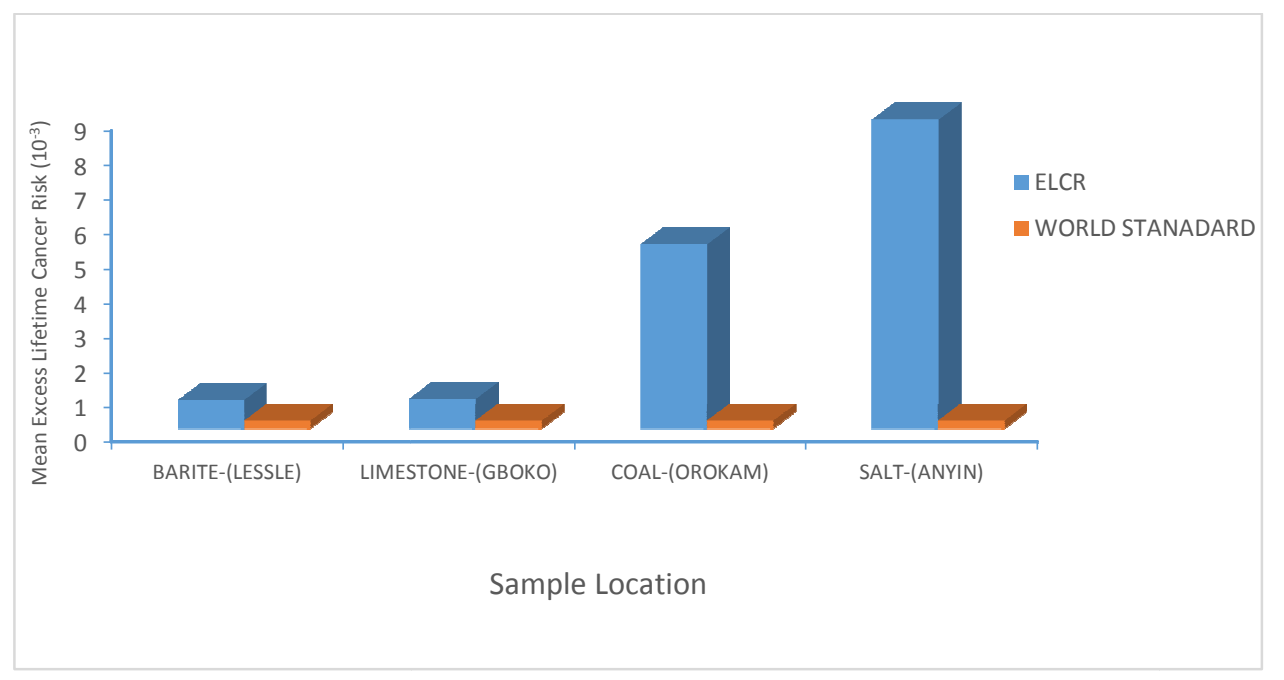

Fig. 3. Comparison of mean ELCR of mineral deposition field with World Safe limit value

\subsubsection{Annual effective dose equivalent (AEDE)}

The AEDE can give a clue on indication of radiological contamination in an outdoor environment which may result to inhalation of high level of radon gas emitted and its progeny from the mining activity that can lead to lung cancer from accumulated doses [15]. Measured absorbed gamma dose rates were used to calculate the annual effective dose equivalent (AEDE) received by individuals within and around the selected mining fields. In calculating AEDE, dose conversion factor of $0.7 \mathrm{~Sv} / \mathrm{Gy}$ and the occupancy factor for outdoor of $0.25(6 / 24)$ was used. The occupancy factor for outdoors was calculated based upon interviews with peoples of the area. People of the study area spend almost 6 hours outdoors due to the nature of their routine. The annual effective dose equation was estimated using the following relation [16]:

AEDE (outdoor) $(\mathrm{mSv} / \mathrm{y})=$ Absorbed dose rate $(n G y / h) \times 8760 h \times 0.7 S v / G y \times 0.25$

The annual effective dose equivalent for the barite, limestone, lead, coal and salt deposition fields of Benue state ranges from 0.19 to 0.43 $\mathrm{mSvy}^{-1}, 0.27$ to $3.62 \mathrm{mSvy}^{-1}, 1.52$ to $2.80 \mathrm{mSvy}^{-1}$, and 3.04 to $3.97 \mathrm{mSvy}^{-1}$ respectively. 


\subsubsection{Excess life cancer risk (ELCR)}

The probabilities of contacting cancer by the mine workers and residents of the study area who will spend all their life time in this environment can be estimated using the excess lifetime cancer risk (ELCR) even in the absence of outbreak radioactive components.

The linear no threshold (LNT) hypothesis extrapolation from evidence-supported, high-dose effects to low-dose responses claims that all acute ionizing radiation exposures down to zero are harmful. The harm is proportional to dose and is cumulative throughout life, regardless of how low the dose rate is [17]. This study is based on the traditional worldwide radiation protection standards for late (stochastic) effects which are based on the LNT hypothesis [18].

The annual effective dose calculated was used to estimate the excess lifetime cancer risk (ELCR) is calculated using equation (3).

$E L C R=A E D E \times$ Average duration of life $(\mathrm{DL}) \times$ Risk factor (RF)

Where AEDE, $D L$ and $R F$ is the annual effective dose equivalent, duration of life (70 years) and risk factor $\left(\mathrm{Sv}^{-1}\right)$, fatal cancer risk per sievert. For low dose background radiations which are considered to produce stochastic effects, ICRP 60 uses values of 0.05 for the public $[3,19]$. ELCR ranges from (0.62 to 1.41) $\times 10^{-3}$ with an average of $0.82 \times 10^{-3}$ for barite deposit fields, from (0.88 to 11.95$) \times 10^{-3}$ with an average of $0.86 \times 10^{-3}$ for limestone deposit fields while ELCR for coal deposit fields range from (5.01 to $9.25) \times 10^{-3}$ with a mean value of $5.33 \times 10^{-3}$. The ELCR of salt deposit fields ranges from (8.48 to 13.11) $\times 10^{-3}$ with a mean value of $8.94 \times 10^{-3}$.

\subsection{Discussion}

The terrestrial radiation level and radiation parameters of the four mine deposit fields (Lessle, Gboko, Otukpo and Akuana) of Benue state and its environs was determined with two well-calibrated radiation meters and the results are presented in Tables 1 to 5 . The values of radiation exposure level range from 0.017 (Nyamge area) to 0.032 (Akegh-Dyege) $\mathrm{mRh}^{-1}$ in theLesslebarite deposit fields. About $96.7 \%$ of the values obtained are higher than the ICRP standard of $0.013 \mathrm{mRh}^{-1}$ for normal background ionizing radiation and for the host community with value of $0.011 \pm 0.008 \mathrm{mRh}^{-1}$. The results show that higher values are as a result of the anthropogenic activities in the field which have exposed radioactive elements in the mine fields. The highest radiation level recorded at AkeghDyege and Lessle mine sites may be attributed to the anthropogenic activities which have left loose the geology of the host rock (sandstone, basement gneisses) in the trough. The consistent high values obtained in the mine field and nearby communities may be seen from spatial vein deposits which cut across the communities. These vein barites are usually extracted as a by or co-product of lead-zinc mining and persisted into the basement complex [20]. The radiation exposure rates at the limestone and coal mine deposit fields of Benue state ranges from 0.017 (Gboko Community) to 0.031 (Gboko Factory) $\mathrm{mRh}^{-1}$, and 0.011 (Otukpo area) to 0.024 (Otukpa area) $\mathrm{mRh}^{-1}$. About $42 \%$, of the limestone mine fields sampling points are higher than ICRP standard of $0.013 \mathrm{mRh}^{-1}$ and $38 \%$ of the coal mine fields sampling points are higher than ICRP standard of $0.013 \mathrm{mRh}^{-1}$ respectively. The values obtained at the limestone and coal mine deposit fields host communities (Amua community and Owukpa community) are quite lower than those obtained in the mine fields. In coal mining fields, Otukpa and Owukpa areas sample points have higher values of $0.024 \mathrm{mRh}^{-}$ and $0.021 \mathrm{mRh}^{-1}$ radiation exposure. In Akuana mine fields, the value of radiation exposure rate for salt range from 0.021 to $0.034 \mathrm{mRh}^{-1}$. About $44 \%$ of the values recorded here are higher than the ICRP standard for normal background radiation level. The mean exposure rate of the four mine deposit fields were found to be higher than the value obtained in Akwa-lbom state (0.007-0.015 mR/hr) [21]. Also values obtained are higher than the $0.018 \pm 0.004 \mathrm{mRh}-1$ value reported for some solid minerals mining environment in Enugu state [22] and other previously reported value in solid mineral environment in Nigeria $[23,24]$. Results obtained here are relatively lower than the results obtained in mine tailings of Awo and Ede, Osun state [25] and in Akwanga, Jos, Plateaus state, Nigeria [26] where mining activities have spanned over many years.

The variation of gamma dose rates from place to place may be attributed to changes in weathering conditions. UNSCEAR have related that change in weathering conditions causes alteration in radon posterity concentration in air due to soil moisture, rainfall and snow [27]. High absorbed dose rates were obtained in all the mineral 
deposition fields; these may be due to mining of the mineral composition of the rock forms which may be rich in radioactive bearing minerals [27]. The absorbed dose of radiation estimated in the barite deposit fields (Lessle) ranges from 95.7 to 278.4 nGyh $^{-1}$ with mean value of 161.53 nGyh $^{-1}$ and the limestone deposit fields (Gboko) ranges from 113.1 to $269.7 \mathrm{nGyh}^{-1}$ with mean value of $182.70 \mathrm{nGyh}^{-1}$ while the absorbed dose rate at the coal deposit fields (Owukpa-Orokam) ranges from 69.6 to $208.8 \mathrm{nGyh}^{-1}$ with mean value of 120.35 nGyh $^{-1}$ while the absorbed dose rate for salt lake deposit fields (Akuana) ranges from 130.50 to 295.80 nGyh $^{-1}$ with mean value of $201.84 \mathrm{nGyh}^{-1}$. The values reported for salt and limestone mine fields are higher than those reported barite and coal mine fields. Mean outdoor gamma dose rate measured for this study are higher than the values previously reported in South Lebanon [19], in Poonch District [8] (106 nGyh and $102 \mathrm{nGyh}^{-1}$ ) respectively. The measured outdoor gamma dose rates are also within the values reported in Turkey (78.3-135.7 $\mathrm{nGyh}^{-1}$ ) [26]. The highest outdoor gamma dose rate measured at AkeghDyege (barite) (278.4 nGyh ${ }^{-1}$ ), Gboko Factory (limestone) (269.7 nGyh ${ }^{-1}$ ), Otupka Area (coal) (208.8 nGyh ${ }^{-1}$ ) and Akuana Salt Lake (salt) (295.8 $\mathrm{nGyh}^{-1}$ ) were higher than the values previously reported in South Lebanon( 106 nGyh $^{-}$ $\left.{ }^{1}\right)$ [19], and in Poonch District (102 nGyh $\left.{ }^{-1}\right)$ [8]. The measured outdoor gamma dose rates are also higher than the values reported in Turkey (78.3- 135.7 nGyh $^{-1}$ ) [26]. This could be due to dissimilarities in the activities that enhance the exposure of the geologic constituent of different areas. The absorbed doses estimated are higher than the world permissible value of $89.0 \mathrm{nGyh}^{-1}$. The annual effective doses estimated in the four mineral deposition fields of Benue state (barite (Lessle), limestone (Gboko), coal (OwukpaOrokam) and salt (Akuana)) were higher than the results obtained in Jhelum valley [9] and higher than world average of $0.48 \mathrm{mSvy}^{-1}$ in the barite and limestone deposition fields and lower than the world average at the coal and salt lake deposition fields. Excess lifetime cancer risks estimated for the entire studied deposition fields were higher than the values obtained by in Ogun River [4], in Poonch, Turkey [8], and in Greece [28].

The values were found to be higher than average world standard of $0.29 \times 10^{-3}$ as shown in Fig. 3 . The consequence of this is that individuals exposed to this radiation may likely develop cancer within their lifetime due to ionization of tissues.

\section{CONCLUSION}

The terrestrial radiation due to solid minerals and sand in mining sites- Lessle, Gboko, Orokam and Akuana and the minerals fields of Benue State have been carried out. We conclude that

1. The Background ionizing radiation in all mineral deposition sites are above those of the host communities.

2. The mean absorbed dose rate (D) in all mineral fields are higher than the world average permissible value and greater than the world population weighted average dose rates.

3. The mean annual effective dose equivalent rate (AEDE) in all mineral fields is higher than the results obtained by other workers in similar environment and world average acceptable values.

4. The ELCR calculated in mineral fields are higher than safe value.

The high level of gamma dose rates obtained may not have any immediate health hazards but could lead to some radiological problems for long term exposure of people living or working around the mine fields, since the fields are radiologically degraded.

\section{COMPETING INTERESTS}

Authors have declared that no competing interests exist.

\section{REFERENCES}

1. Bradshaw MJ. Population, resources, development and the environment. In: Daniels $\mathrm{P}$, et al. eds. An Introduction to Human Geography: Issues for the 21st century. 2nd ed. (Section 2); 2005.

2. Tchokossa P, Olomo JB, Balogun FA, Adesanmi CA. Radiological study of soils in oil and gas producing areas in Delta State, Nigeria. Radiat. Prot. Dos. 2012; 153(1):121-126.

DOI: $10.1093 / \mathrm{rpd} / \mathrm{ncs} 101$

3. Taskin H, Karavus M, Ay P, Topozoglu A, Hindiroglu S, Karahan G. Radionuclide concentrations in soil and life time cancer risk due to gamma radioactivity in 
Kirklareli, Turkey. Journal of Environmental Radioactivity. 2009;100:49-53.

4. Okeyode IC, Jibiri NN. Excess lifetime cancer risk associated with the use of sediments from Ogun River as building materials. Research Journal of Physics. 2013;7:1-8.

5. Avwiri GO, Owate IO, Enyinna PI. Radionuclide concentration survey of soil, sediment and water in Aba River, Abia State, Nigeria. Scientia Africana. 2005;4(1-2):67-73.

6. Chad-Umoren YE, Nwali AC. Assessment of specific activity concentration and percentage contribution of 226Ra, 232Th and $40 \mathrm{~K}$ to absorbed dose rate of the Port Harcourt refinery company host community. Scientia Africana. 2013;12(1): 7-19.

7. Chad-Umoren YE, Ohwekevwo. Influence of crude oil spillage on the gamma radiation status of water and soil in Ogba /Egbema/Ndoni area, Nigeria. Energy and Environment Research. 2013;3(2):1-8.

8. Rafique M, Basharat M, Azhar Saeed R, Rahamn S. Effect of geology and altitude on ambient outdoor gamma dose rates in district poonch, Azad Kashmir, Carpathian. Journal of Earth and Environmental Sciences. 2013;8(4):165-173.

9. Rafique M, Rahman SU, Basharat M, Aziz W, Ahmad I, Lone KA, Ahmad K, Matiullah. Evaluation of excess life time cancer risk from gamma dose rate in Jhelum valley. Journal of Radiation Research and Applied Sciences. 2014;7:29-35.

10. Avwiri GO, Ononugbo CP, Nwokeoji IE. Radiation hazard indices and excess lifetime cancer risk in soil, sediment and water around Mini-Okoro/Oginigba creek, Port Harcourt, Rivers State, Nigeria. Comprehensive Journal of Environment and Earth Sciences. 2014;3(1):38-50. ISSN-2315-7488. Knowledge base Publishers.

11. Kogbe CA, Torkeshi A, Osiyuk D, Wozney DE. Geology of Makurdi sheet 257 the middle valley, Nigeria. Occasional Publication, Dept. of Geology, Ahmadu Bello University. Zaria; 1978.

12. Abaa SI. Origin of the Benue trough and its economic significance to Nigeria. Being the 2nd Inaugural lecture of Benue State University, Makurdi, Nigeria; 2004.

13. Benue State Ministry of Environment and Solid Mineral Development. Benue State investment potentials in solid minerals. Government Bulletin. 2006;5.

14. Ononugbo CP, Avwiri GO, Komolafe E. Radioactivity of Aba river and estimation of radiation risk of the populace. IOSR Journal of Applied Physics (IOSR-JAP). 2016;8(3):43-49.

e-ISSN: 2278-4861

Available:www.iosrjournals.org

15. Ademola JA, Onyema UC. Assessment of natural radionuclides in fly ash produced at Orji River thermal power station, Nigeria and the associated radiological impact. Nat Sci. 2014;6:752-759.

DOI: $10.4236 / \mathrm{ns} .2014 .610075$

16. UNSCEAR. Ionizing radiation: Sources and biological effects report to the general assembly with scientific annexes. United Nations Scientific Committee for Effects of Atomic Radiation New York, United Nation. 2000;44-89.

17. Mishra KP. Carcinogenic risk from lowdose radiation exposure is overestimated. J Radiat Cancer Res. 2017;8:1-3.

18. Stewart FA, Akleyev AV, Hauer-Jensen M, Hendry JH, Kleiman $\mathrm{NJ}$, et al. ICRP publication 118: ICRP statement on tissue reactions and early and late effects of radiation in normal tissues and organs Threshold doses for tissue reactions in a radiation protection context. Ann ICRP. 2012;41:1-322.

19. Mohammed A, Obeissi K, Omar ES, Khaled Z, Ibrahim R. Assessment of indoor and outdoor radon levels in South Lebanon. Springer. 2014;214-226.

20. Michael Oden. Barite veins in the benue trough: Field characteristics, the quality issue and some tectonic implications. Environment and Natural Resources Research. 2012;2(2):21-31.

Available:www.ccsenet.org/enrr

21. Akpabio LE, Efuk ES, Essien K. Environmental radioactive levels in Ikot Ekpene, Nigeria. Nig. J. Space Res. 2005;1:80-88.

22. Osimobi JC, Agbalagba EO, Avwiri GO, Ononugbo CP. GIS mapping and background ionizing radiation (BIR) assessment of solid mineral mining sites in Enugu State, Nigeria. Open Access Library Journal. Creative Commons Attribution International License (CC BY); 2015.

Available:http://creativecommons.org/licen ses/by/4.0/ 
23. Balogun FA, Mokobia CE, Fasasi MK, Ogundare FO. Natural radioactivity associated with bituminous coal mining in Nigeria. Nucllnst Methods Phys Res A. 2003;505:444-448.

24. Mokobia CE. Determination of the radiological health indices of using natural kaolin. Scientia Africana. 2011;10(1):29-33.

25. Adewale OO, Tubosun IA, Ojo JO. Assessment of terrestrial naturally occurring radioactive material in soil and mine tailings of Awo and Ede, Osun-state, Nigeria. Ife Journal of Science. 2015;17(1): 199-209.
26. Erees FS, Akozcan S, Parlak Y, Cam S. Assessment of dose rates around Manisa (Turkey). Radiation Measurements. 2006;41(5):598-601.

27. Sadiq AA, Agba EH. Background radiation in Akwanga, Nigeria. Journal of Working and Living Environmental Protection. 2011;8(1):7-11.

28. Clouvas A, Xianthos S, AntonopoulosDomis M. Radiological map of outdoor and indoor gamma dose rates in Greek urban areas obtained by in situ gamma spectrometry. Radiat Prot Dosim. 2004;112(2):267-275.

(C) 2017 Olanrewaju and Avwiri; This is an Open Access article distributed under the terms of the Creative Commons Attribution License (http://creativecommons.org/licenses/by/4.0), which permits unrestricted use, distribution, and reproduction in any medium, provided the original work is properly cited.

Peer-review history:

The peer review history for this paper can be accessed here:

http://sciencedomain.org/review-history/19214 